Article

\title{
Transformation toward a Secure and Precaution-Oriented Energy System with the Guiding Concept of Resilience-Implementation of Low-Exergy Solutions in Northwestern Germany
}

\author{
Urte Brand * and Arnim von Gleich \\ Department of Technology Design and Development, University of Bremen, Enrique-Schmidt-Str. 7, \\ 28359 Bremen, Germany; E-Mail: gleich@uni-bremen.de \\ * Author to whom correspondence should be addressed; E-Mail: ubrand@uni-bremen.de; \\ Tel.: +49-421-218-64888; Fax: +49-421-218-9864888.
}

Academic Editor: Stefan Gößling-Reisemann

Received: 1 June 2015 / Accepted: 3 July 2015 / Published: 10 July 2015

\begin{abstract}
Climate changes, incidents like nuclear disasters, and associated political objectives call for significant changes to the current energy system. Despite these far-reaching transformation processes, within the intended changes security of supply and precautions against the possible consequences of climate change must be ensured. Consequently, the question arises how to direct energy systems. In this context the processes of guiding orientations with the help of the guiding concept of "resilient systems" and feasible and addressee-oriented guiding design principles can be an option to provide guidance in transformation processes. However, it is questionable whether and how such processes are effective in the long term and if they are able to give direction by doing so. Within the framework of empirical studies of a regional guiding orientation process for the energy system of Northwestern Germany, the long-term effectiveness of the process and its spread resilient guiding design principles of "low-exergy solutions" and "climate-adapted and energy-efficient refrigeration" has been confirmed. Such effectiveness requires the implementation of a four-phase guiding orientation process which takes content-related and process-related effectiveness factors into account. Therefore, the study shows how regional energy systems can be designed toward the major challenges of ensuring security and precaution.
\end{abstract}


Keywords: climate adaptation; sustainability; efficiency; circular economy; cooling; climate change; refrigeration; renewable energies

\section{Introduction}

Political objectives due to challenges like climate change caused by the greenhouse effect, the finite nature of fossil fuels, and incidents such as the nuclear disaster of Fukushima require a substantial transformation of the current energy system to ensure the security of supply, protection from technological risks, and precautions against possible consequences of climate change. On the other hand, these transformation processes also involve risks, e.g., by the unresolved deal with fluctuating renewable energies, which could potentially involve supply shortages and electricity grid loads. Against this background, the demand for an energy system which still provides precaution and security despite these drastic changes is growing. This puts into focus the issue of how the socio-technical energy system and transformation processes within can be influenced in a desired direction.

Research approaches which deal with the topic to give direction in systems and its innovation and transformation processes are, e.g., the "transition management" [1], the "constructive technology assessment" [2], and the "turtles model" (also known as multi-impulse model) [3]. On the one hand, these theoretical concepts have in common that they attach to certain factors which can provide directional impetus but they cannot control transformation processes (including innovation processes). Taking into account inherent dynamics, path dependencies, and new insights leading to adaptation or regeneration of objectives and measures, these factors are able to give direction instead of ensuring direction. On the other hand, all of these approaches assume that the implementation of future representations by processes of guiding orientations, visions or scenarios is important for outlining the intended direction.

Processes of guiding orientations which can take up a desired direction like the world views of security and precaution with the help of socio-technical guiding concepts, simultaneously desired and deemed feasible, collectively communicated and agreed ideas about the future, and specified feasible guiding design principles can provide orientation in complex transformation processes and thus provide directional impetuses toward desired world views [4]. One thinks of the guiding concept of "sustainability" which has supported impressively the provision of direction in socio-technical systems in the past few decades.

However, the question arises whether we can use guiding orientation processes specifically to propagate guiding orientations for directing socio-technical systems in a desired direction or if guiding orientations emerge arbitrarily. This is an issue which has been discussed controversially in the technological genesis research and social sciences for many years [5]. Retrospective studies in the 1990s in the field of computer science development have shown that guiding orientations may become more important in the course of technological innovation processes, but they may also lose again. Certain guiding principles which are taken up and formulated at the beginning of innovation processes could not shape technologies [6,7]. It has to be remembered though that these investigations are related to very concrete, practical-oriented guiding orientations in technological innovation processes, in our 
understanding guiding design. More abstract guiding concepts in systemic transformation processes, however, were neglected in retrospective or even process-related studies. Nevertheless, guiding concepts could be an important instrument for shaping. If you look for example, at systemic transformation processes like the energy turnaround, which can be certainly described as a common task, you see that their challenge lies not only in the field of technology but also in the fundamental changes and new features of the relations and interfaces between these technologies and the society within the energy turnaround [8]. Issues such as network expansion and the share of renewables in an overall energy mix and related land-use conflicts like the energy price developments ultimately imply significant social conflicts. This requires an addressee-oriented and targeted group specific participation of civil society actors which could be done for example by guiding concepts which are capable of reducing complexity, synchronizing actors, and giving orientation.

To what extent guiding orientation processes could be used to give direction in transformation processes within the energy system, by using such guiding concepts, was investigated in the context of a scientifically initiated guiding orientation process implemented in the energy system of Northwestern Germany. In this process the climate change and its direct and indirect consequences as well as the associated need for adaptation of the considered regional energy system toward security of supply and precaution was focused. With a view to a guiding concept taking up world views adequately and giving orientation, the research team pursued the approach of "resilience" which aims at systems maintaining their services in spite of internal and external disturbances [9]. Within the guiding orientation process the guiding concept was supposed to be established in the regional energy system by the development of specific resilient guiding design together with systemically relevant actors from industry, civil society, politics and science. Therefore, the researchers implemented several flagship projects serving as examples for a "resilient energy system" with the intention to initiate a transformation toward a more secure and precautionary regional energy system in terms of direct and indirect climate effects.

We will explain in this paper how this process proceeded in detail and how the rather "foreign" approach of resilience was specialized for systemically relevant actors. Moreover, we will demonstrate if and to what extent within the process propagated guiding concept of resilient systems had taken effect over the process period. This means whether and under what conditions the guiding concept guided thinking or even action among the actors of the regional energy system and hence how it was able to give direction. In this context it must be emphasized that guiding orientations cannot give direction on their own but only in interaction with other influencing factors acting on or in socio-technical systems [10]. Extreme occurrences like Fukushima and the following civil society scandals of nuclear technology have only increased guiding concepts such as "sustainability" or " $100 \%$ renewable energies" in the past. Thus, a desired direction requires a certain level of synchronization which is understood as a compatibility of direction impetuses of these influencing factors [11]. Therefore, it should also be examined to what extent this claim of compatibility was to be taken into account in this guiding orientation process or whether there were limits for the process.

After a brief overview of the guiding orientation process with its underlying theoretical works and empirical methods, we will point out the flow of the investigated process, present the results in terms of the aforementioned issues and discuss them in a final section. 


\section{Materials and Methods}

\subsection{Theoretical Principles of Guiding Orientation Processes}

According to the phase model by Dierkes et al. [12] guiding orientation processes can be performed in four general phases which will be described in the context of the case study in more detail (see Section 3). In addition, further guiding influencing factors should also be taken into account. In order to decrease incompatibilities of guiding orientations with their directional impetuses the consideration of these factors can lead to an adaption of the guiding orientations or to an influence of them within the process. As a basis for the identification of the guiding influencing factors serves the turtles model $[3,13]$ which is adapted to socio-technical systems [14]. It based on six external guiding influencing factors and three internal influencing factors which operate to or rather in the socio-technical system and show among one another a reciprocal relationship. These factors which take effect on primarily other influencing factors can be particularly relevant to giving orientation which can vary on the considered system. In addition, there are metafactors, which cannot be influenced by other factors (see Figure 1).

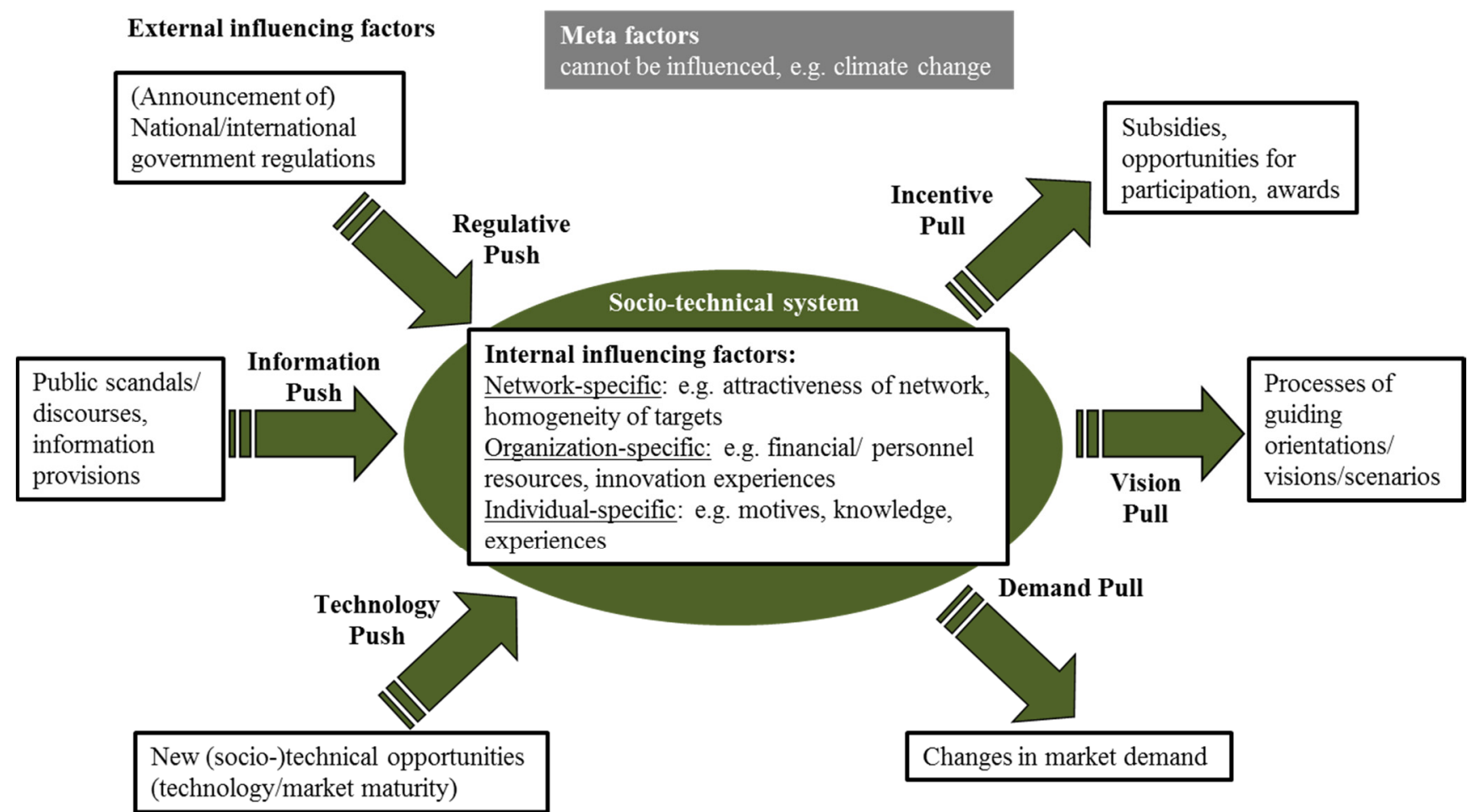

Figure 1. Filled turtles model of socio-technical systems based on $[3,13,14]$.

To what extent such a guiding orientation process can be effective in the long term is the object (amongst others) of the present study. In order for guiding concepts and guiding design principles to develop their desired effect, that is to say, to be orienting and thereby give direction, first their individual and collective integration by guiding orientation processes must take place, which can happen in several, partially parallel stages [15]. In this connection we assume effectiveness when guiding orientation processes lead to the integration of the guiding orientation with the meaning of a guided-thinking in the social exchange [16]. This means that they are considered for example, as relevant or necessary. An even higher effectiveness is manifested then in a guided-action which 
includes a willingness to transfer guiding orientations (willingness to take action) or an actual implementation of guiding orientations (factual action) [15].

\subsection{Empirical Survey and Analysis Methods}

For the research study, which was carried out in the Northwestern Germany (metropolitan region Bremen-Oldenburg) and conducted as a guiding orientation process for the energy system regarding the previous questions, different survey and analysis methods of the qualitative and quantitative empirical social research were applied (see Figure 2). On the one hand, as the guiding orientation process progressed (February 2009 to November 2013), participatory observations and discussions in the research field were held on internal project team meetings as well as events with actors of the energy system of Northwestern Germany.

On the other hand, subsequent to the guiding orientation process two e-mail surveys were conducted as part of a longitudinal analysis in December 2013 and in May 2015 as well as a series of interviews from August to October 2014. Within the scope of the two e-mail surveys 14 companies were interviewed which participated in the context of the guiding orientation process in a conducted series of events (13 refrigeration technology companies, one energy consultant). In the first survey six companies (43\%) responded and in the second survey seven companies (50\%). The qualitative guideline interviews were conducted with 11 participants of the guiding orientation process (three refrigeration technology companies, two energy supply companies, one agriculturist, one external project scientist, two internal project scientists) who were selected by company affiliation and participation period.

The evaluation of the participatory observation, the discussions in the research field and guideline interviews took place in dependence on the "qualitative content analysis" [17] and the "Leitbild analysis" [18]. The email survey was evaluated quantitatively in form of a frequency distribution.

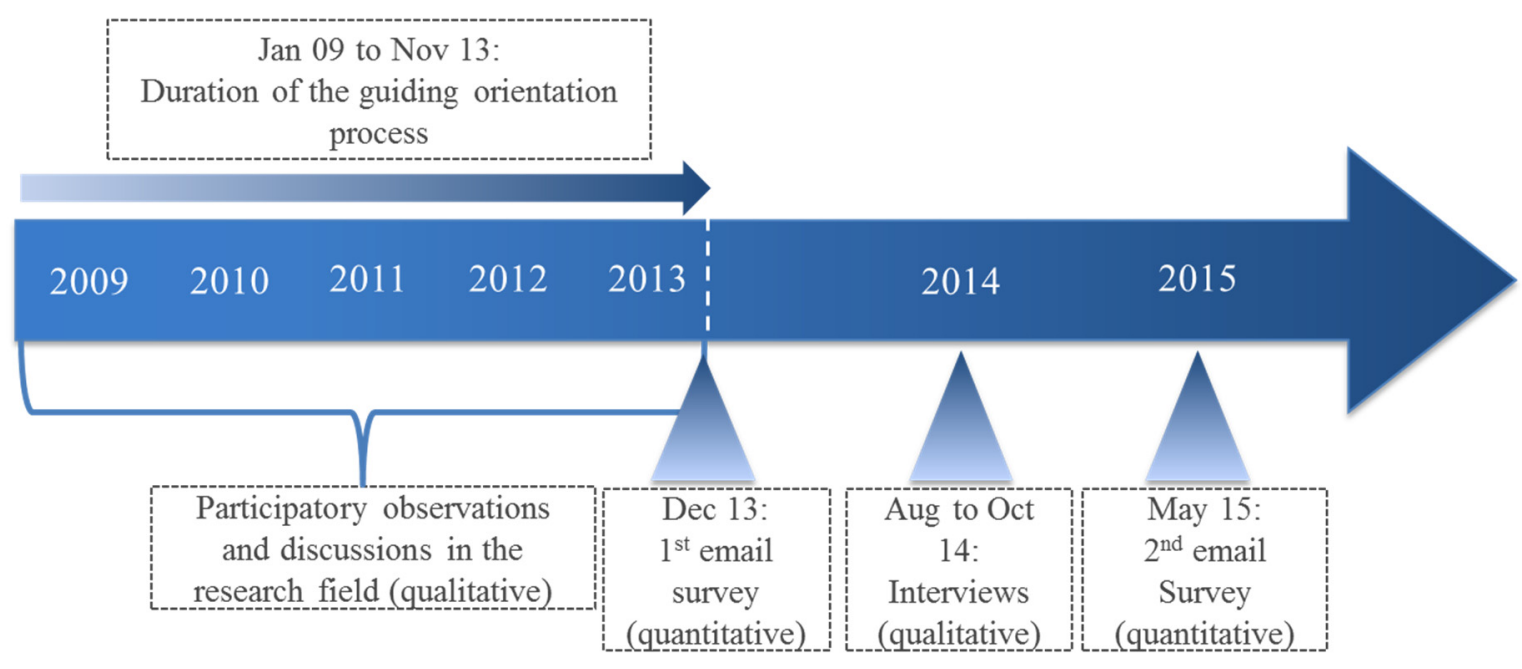

Figure 2. Conducted empirical research methods during and after the guiding orientation process.

\section{Case Study: Implementation of Low-Exergy Solutions in Northwestern Germany}

The consequences of climate change affecting further rising temperatures, seasonal changes in precipitation, sea level rise, and possibly increased incidence of extreme events create major challenges for regions. In particular, coastal areas are considered to be climate-sensitive food and trade 
fields due to their exposure to the sea [19]. Such a progressive and already inevitable climate change calls for the adaptation to climate change alongside efforts for climate protection so that systems like the socio-technical energy system do not fall into extreme crises or even collapse [20].

The research project "nordwest2050-Prospects for Climate-Adapted Innovation Processes in the Metropolitan Region Bremen-Oldenburg in Northwestern Germany" supported by the Federal Ministry of Education and Research (duration: 2009 to 2014) faced up to this issue. Its aim was the development of climate change adaptation measures (guiding design principles) as well as their demonstration with exemplary flagship projects and regional spreading together with systemically relevant actors within a guiding orientation process for the energy system of the coastal area Bremen-Oldenburg in Northwestern Germany (about 2.7 million inhabitants).

\subsection{Phase 1: Take-Up of the World Views of "Security" and "Precaution" with the Help of the} Problem-Solving Guiding Idea of "Resilience" and Development of the Guiding Concept of "Resilient Systems" and Its Elements

This process was initiated as a result of the challenge ensuring supply security of the regional energy system and guaranteeing early precautions despite the climate change and its possible consequences (metafactor). Therefore, the world views of "security" and "precaution" represent the desired direction of the energy system and should be taken up within the guiding orientation process (see Figure 3). As a first approach, the guiding idea of "climate change adaptation" has been used by a scientific project team whose intense measures respond to unforeseen challenges like impacts of climate change within the meaning of a "what-if approach". During the process, however, it turned out that unforeseeable disturbances such as weather extremes and complex cause-effect relationships between the various regional, national, and international systems (e.g., international financial sector, demographic change) are not taken into account with this approach. Thus, the project team decided to pursue the guiding idea of "resilience" as an advanced orientating framework toward security and precaution for the guiding orientation process. Based on the concept of ecological resilience by Holling [21] and the definitional works of Brand [22] the project team transferred the approach of resilience to socio-technical systems in intensive communication processes with external project researchers. The result was the guiding concept of "resilient systems" which are systems that maintain their system services in terms of an "(almost)-no-matter-what-comes-approach" even in spite of system internal and external surprises, such as unforeseeable incidents.

This definition includes two important differences from the previously formulated definitions of resilience [21,23,24]. Firstly, resilience as it is used in the project does not mean the conservation of the system structures but the conservation of the system services. Therefore, it may be necessary to change the system structures radically to maintain the system services. For example, the energy system services could be defined quantitatively and qualitatively by technical parameters like the provided connected load which was agreed with consumers and by non-technical parameters like global warming potential and social acceptability [25]. Secondly, several studies apply resilience as an analytical category, i.e., they introduce the term to analyze or measure the resilience of systems. In contrast, and to distance themselves from the principle of readjustment and subsequent improvement the project team used resilience as a guiding concept to design socio-technical systems toward security and precaution [25]. 
For determining the guiding concept of resilient systems in more detail the project team derived system capabilities, structures and resources $[4,26]$, so called guiding concept elements, by reflecting other works of resilience [27,28] and resilient capabilities of living organisms and ecosystems (nature as model) (see Table 1). They show which elements systems they have to be equipped with in order to make them more resilient against predictable and unpredictable disturbances.

Table 1. Specification of the guiding concept of "resilient systems" into guiding concept elements and design elements using the example of the energy system based on [29].

\begin{tabular}{|c|c|c|}
\hline \multicolumn{2}{|c|}{ Guiding Concept Elements } & Design Elements \\
\hline \multirow{4}{*}{$\begin{array}{c}\text { System } \\
\text { capabilities }\end{array}$} & Robustness & Decentralized generation; repairing mechanism/routines \\
\hline & Adaptivity & $\begin{array}{l}\text { Learning capability; integration of different energy sources; } \\
\text { adaptation to strongly fluctuating energy generation and demand }\end{array}$ \\
\hline & Capabilities to innovate & $\begin{array}{l}\text { System open to innovative energy sources, technologies, and } \\
\text { infrastructures; capability of recycling, and dismantling }\end{array}$ \\
\hline & Capabilities to improvise & $\begin{array}{l}\text { Stockpile of unplanned resources; redundancy; } \\
\text { regular emergency exercises; } \\
\text { recourse options to expertise in short time }\end{array}$ \\
\hline \multirow{3}{*}{$\begin{array}{l}\text { System } \\
\text { resources }\end{array}$} & $\begin{array}{l}\text { Access to energy, } \\
\text { information, and material } \\
\text { resources }\end{array}$ & $\begin{array}{l}\text { Safe access to raw materials and recycling; smart metering; } \\
\text { strengthening regional supply }\end{array}$ \\
\hline & $\begin{array}{l}\text { Wide range and diversity } \\
\text { of resources }\end{array}$ & Using waste heat and material residues \\
\hline & Modularity & Standardized interfaces; substitutability of system components \\
\hline \multirow{6}{*}{$\begin{array}{c}\text { System } \\
\text { structures }\end{array}$} & Functional variety/diversity & $\begin{array}{l}\text { Conversion between energy sources } \\
\text { (possibly power-to-gas, power-to-heat) }\end{array}$ \\
\hline & Redundancy & N-1 security; reserve power plants; intermeshed networks \\
\hline & Feedback mechanism & Dynamic management of generation, storage, and demand \\
\hline & Buffer & Storages of heat/cold, electricity, gas \\
\hline & Dampers & Management of large consumers; regulatory mechanisms; costs \\
\hline & Optional networking & $\begin{array}{l}\text { Optional (de)coupling of different energy grids; } \\
\text { disconnection from the grid; cellular systems/grids }\end{array}$ \\
\hline
\end{tabular}

In this context it has to be taken into account that the resilience of a system can only be improved through the coordinated interaction of the guiding concept elements. All elements cannot be implemented to the same extent and sometimes they could even be in a kind of conflicting relationship between each other [29]. Furthermore, some of the presented guiding concept elements are in a sharp contrast to key strategic elements of sustainability. For example, ensuring redundancies and storages may result in a less efficient use of resources at the same time. On the other hand, resilience represents an important complement to the guiding concept of sustainability, namely the provision for risks, which is gaining in importance due to recent past incidents such as terrorist attacks, international financial crises as well as natural and nuclear disasters [29]. 


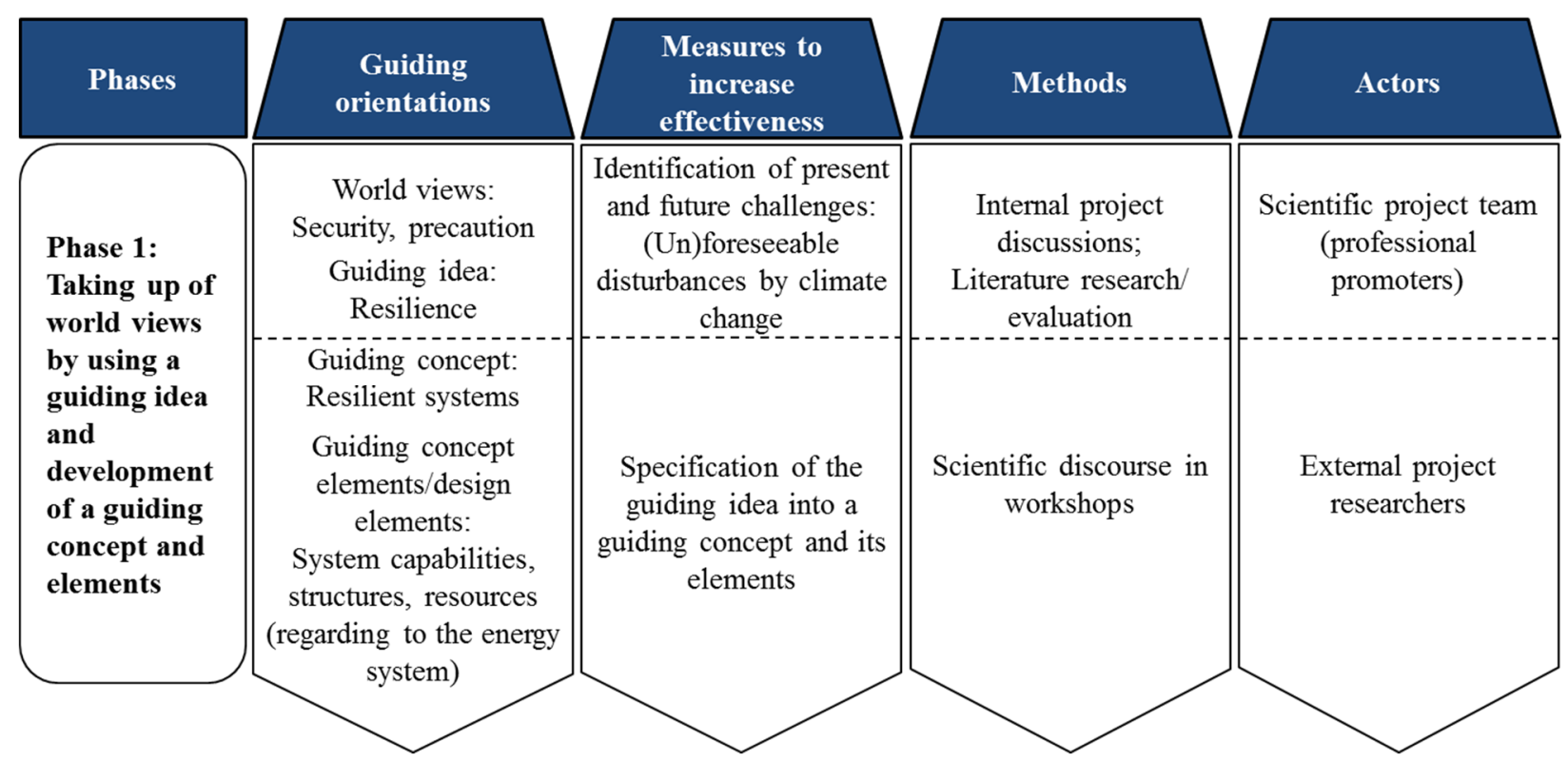

Figure 3. Phase 1 of the regional guiding orientation process.

During the execution of the process the initial presumption was confirmed that resilience is a highly abstract term which seems to be infrequently used in the current language beyond the sciences. Accordingly, the approach led to communication problems with civil-societal and political actors in spite of the specialized guiding concept elements. In order to avoid conceptual misunderstandings, the scientific project team developed specific design elements for the energy system based on the guiding concept elements which show feasible instructions to operationalize a resilient energy system [29-31] (see Table 1).

\subsection{Phase 2: Specification of the Guiding Concept of "Resilient Systems" into the Guiding Design} Principles of "Low-Exergy Solutions" and "Climate-Adapted and Energy-Efficient Refrigeration" Taking into Account Further Influencing Factors

The project team decided to specify the guiding concept of resilient systems into region-specific guiding design principles in exchange with project external actors of the regional energy system as a bottom-up process and not as a top-down process as it was carried in the beginning of the guiding orientation process. Therefore, this process also helped checking the compatibility of the guiding design principles with directional impetuses of further influencing factors which are mentioned in the turtles model. In this context it was particularly interesting to what extent the region would need resilient guiding design principles at all (demand pull) and which (potential) technologies, actors as well as technical and infrastructural requirements were available for the implementation of guiding design principles in the region (technology push) (see Figure 4).

As part of a vulnerability analysis [25] which was carried out by literature researches and evaluations as well as an exchange with regional energy supply companies, the project team initially analyzed regional climate change impacts and associated needs for adaptation (demand pull). In this regard, the researchers found out that the vulnerability of the regional energy system is less a result of direct climatic effects because regional energy suppliers are already used to dealing with a wide multitude of climatic uncertainties (e.g., through the redundancy in electricity networks (N-1 security) or the 
diversification of primary energy sources suppliers) [32]. Indirect effects which result from extensive transformation processes of the energy system in order to achieve the two-degree target are, however, of a much higher importance. In this context, the electricity grid loads will create future challenges in the course of a growing supply of fluctuating, decentralized and renewable energies.

Against this background, the project team developed the guiding design principle "low-exergy solutions" which means technological solutions (conversion, storage and distribution technologies) use exergetic low ambient energy sources or residual and waste streams (e.g., industrial waste heat, solar thermal energy, geothermal heat and cold) and provide demanded energy services [33,34]. With a view to the elements, which describe the design elements of resilient energy systems, low-exergy solutions can increase the wide range and diversity of resources, make storages available, provide redundancies, and increase the resistance of heat and cold supply through their decentralized generation which can remove strain from the electricity grid and will be particularly relevant when the demand for refrigeration applications will grow due to climate change-induced temperature increases [34]. In addition, new markets and sales opportunities for regional companies can arise through the development and distribution of low-exergy solutions and their connected services. Furthermore, inefficiencies in the electricity and heat supply can be reduced by using already existing useful energy and conversion processes with a higher electrical performance factor (savings of energy and $\mathrm{CO}_{2}$ ) [34].

During a subsequent innovation potential analysis [33] by literature research and expert discussions the scientific project team found out that the necessary low-exergy energy sources as well as the technologies to convert and distribute these sources are available in the investigated region in different stages of development (technology push). However, an adequate combination of these technologies and an identification of appropriate energy services (e.g., industrial/commercial cooling, electricity supply) as well as the information about such systems would still be missing. Therefore, the project team identified combinations which are particularly suitable in relation to their innovativeness, feasibility, potential of resilience, and multiplier effect (application examples) [33].

In exchange with actors from the heat and refrigeration industry (manufacturers, installers, potential operators) the project team discussed the relevance and potential applications of these application examples in a subsequent workshop (demand pull). In this regard, they concluded that the refrigeration market has a need for low-exergy solutions which will be exacerbated by future climate change-induced rising demand for refrigeration applications according to the vulnerability analysis [25]. Thus, the project team focused on the refrigeration market during further processing and specified low-exergy solutions to the guiding design principle "climate-adapted refrigeration".

In the course of the subsequent phase the project team decided consciously to focus less on the approach of climate change adaptation and even less on the infrequently used approach of resilience but more on guiding concepts which are well-established in the refrigeration industry and might have a higher capability of response. During the phase of specification "efficient systems" were identified as a guiding concept which is compatible with the refrigeration industry because efficiency measures are required due to numerous regulations of climate protection and, at the same time, they may also lead to running costs savings. Therefore, the project team specified the guiding design principle into "climate-adapted and energy-efficient refrigeration" within a final step. Hence, the researchers developed two regional-specific guiding design principles in the second phase of the guiding orientation process, "low-exergy solutions" and "climate-adapted and energy-efficient refrigeration" (see Figure 4). 


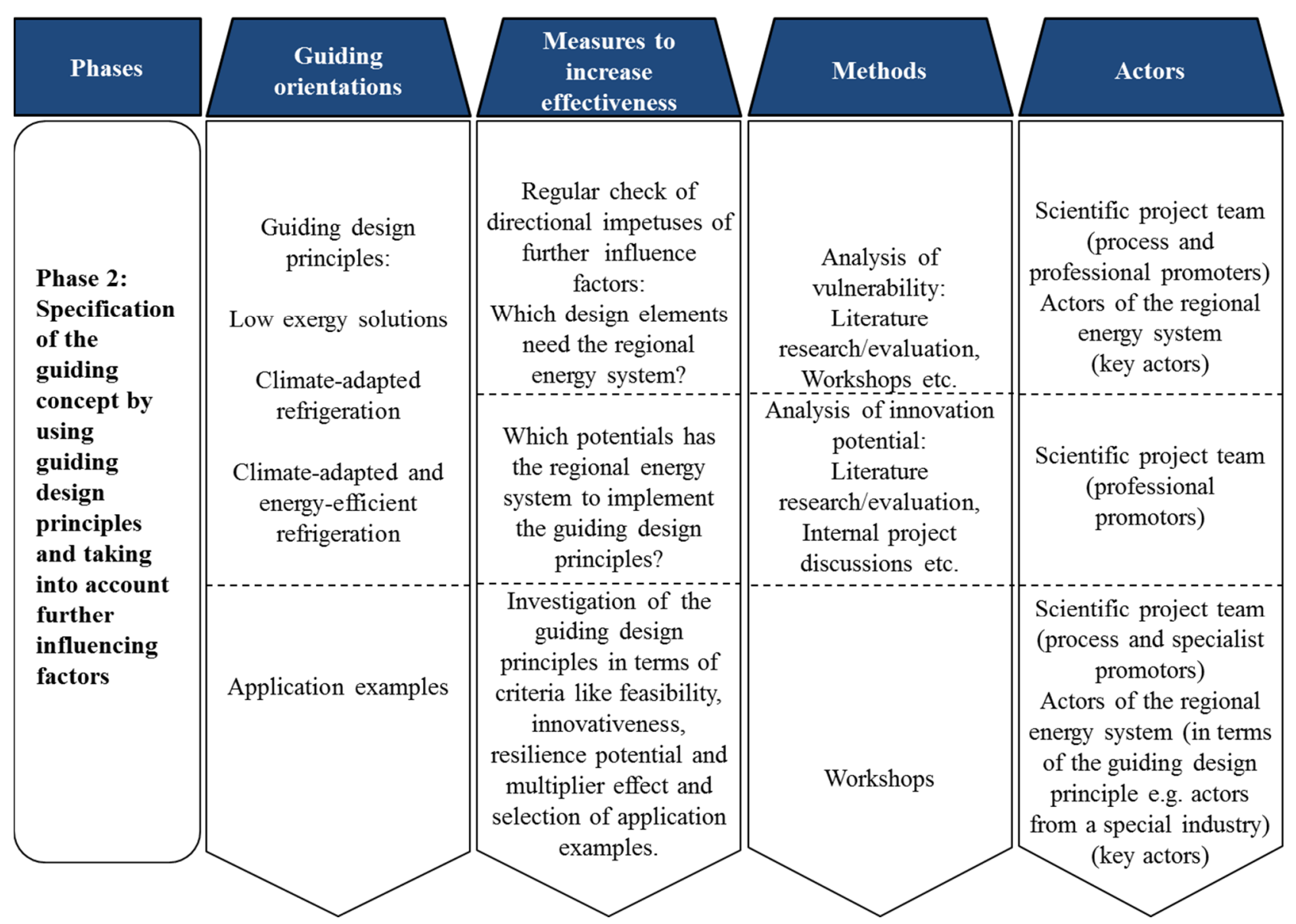

Figure 4. Phase 2 of the regional guiding orientation process.

\subsection{Phase 3: Spreading of the Resilient Guiding Design Principles and Influencing of Incompatible Directional Impetuses}

The resilient guiding design principles and application examples were spread by conducting a series of events with actors from the regional refrigeration industry and a workshop with predominantly system external actors from politics and publishing in professional journals and conferences (see Figure 5).

In the context of the event series with regional actors of the refrigeration industry (manufactures, installers, energy consultants) the project team informed about application examples in the form of regional located and partially within the project implemented climate-adapted and energy-efficient refrigeration technologies which the participants could visit at the events. Besides the information about these solutions the event series served to discuss compatible and incompatible directional impetuses of further influencing factors with the regional actors. In this context three main topics were focused, possible fields of application and service areas as well as inhibiting factors and supportive measures for a climate-adapted and energy-efficient refrigeration in order to look at further external influencing factors like incentive pull and information push as well as internal influencing factors.

Following the series of events the scientific project team presented its discussion and previous analysis results to actors of the energy and climate policy in order to show the relevance of low-exergy solutions in the refrigeration industry for a resilient and thus a secure regional energy system. Furthermore, the project team intended to draw attention to possible political supply measures for their implementation (see Figure 5). 
The guiding orientation process was documented by a written roadmap [34], a draft measure to implement the guiding design principle climate-adapted and energy-efficient refrigeration, which is accessible online. Apart from presentations at conferences, articles have been published in regional journals which report on low-exergy solutions $[35,36]$.

In addition, it should be noted that all previous processes in which external actors participated helped spreading all of the developed resilient guiding design principles, elements and application examples (e.g., the workshops within the vulnerability and innovation potential analysis).

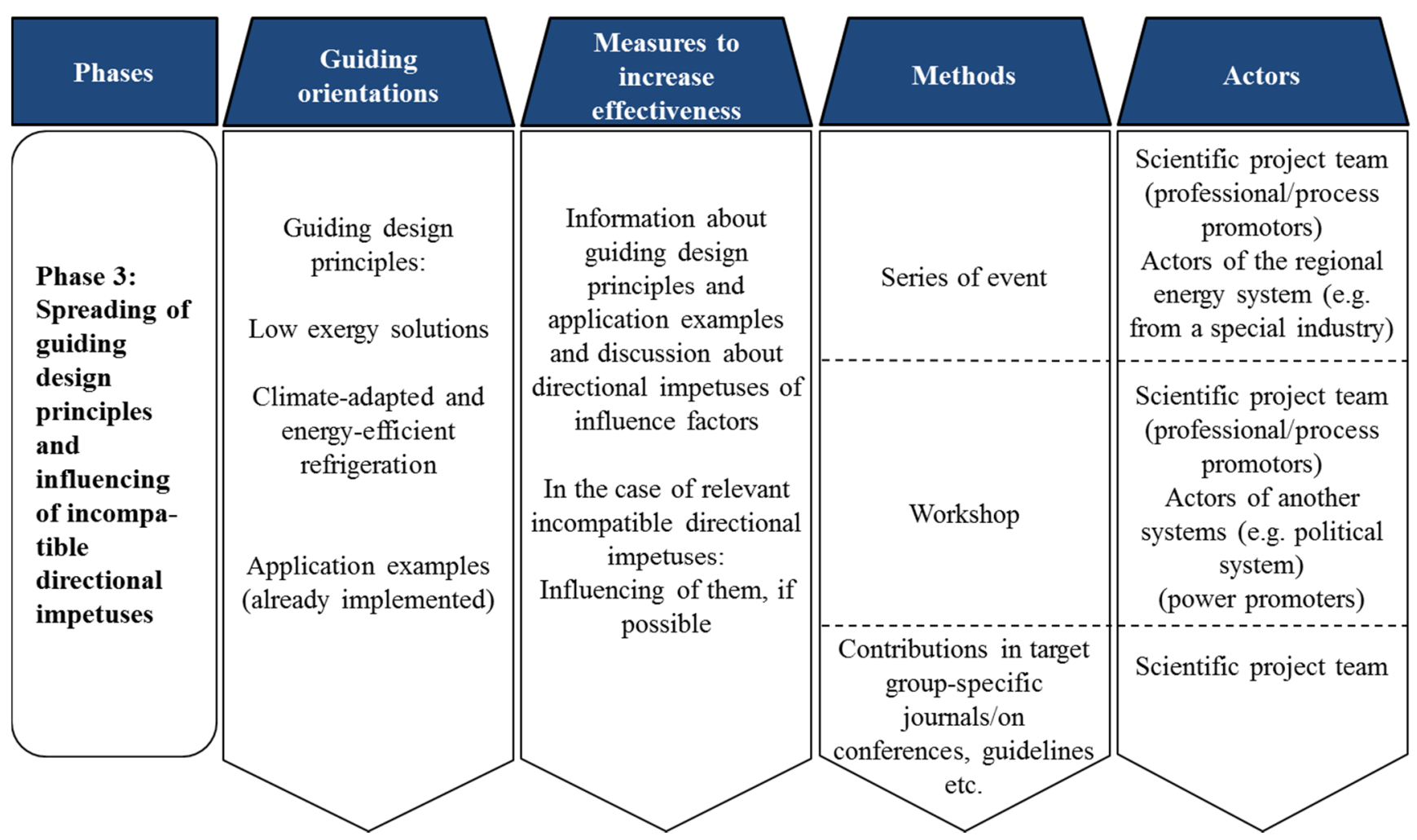

Figure 5. Phase 3 of the regional guiding orientation process.

\subsection{Phase 4: Implementation of the Resilient Guiding Design Principles [37]}

The guiding orientation process initiated first implementations of the guiding design principles by developing, building and partially putting suitable low-exergy solutions (flagship projects) into operation with practice partners from the regional refrigeration industry (see Figure 6). These projects deal with the cooling of turkey barns using an absorption refrigeration system, a biogas plant for converting cellulose-rich substrates according to a cow's stomach-principle and the geothermal cooling of a data center [36]. As models for the region these projects are supposed to demonstrate exemplary implementations of the guiding design principles for energy system actors. 


\begin{tabular}{|c|c|c|c|c|}
\hline Phases & $\begin{array}{c}\text { Guiding } \\
\text { orientations }\end{array}$ & $\begin{array}{l}\text { Measures to } \\
\text { increase } \\
\text { effectiveness }\end{array}$ & Methods & Actors \\
\hline $\begin{array}{l}\text { Phase 4: } \\
\text { Implemen- } \\
\text { tation of } \\
\text { guiding } \\
\text { design } \\
\text { principles }\end{array}$ & $\begin{array}{l}\text { Application examples } \\
\text { of guiding design } \\
\text { principle } \\
\text { Low exergy solutions }\end{array}$ & $\begin{array}{l}\text { Implementation of } \\
\text { selected application } \\
\text { examples }\end{array}$ & $\begin{array}{l}\text { Flagship projects: } \\
\text { (1) Cooling turkey } \\
\text { barns with an } \\
\text { absorption refrigeration } \\
\text { system } \\
\text { (2) Biogas plant for } \\
\text { converting cellulose- } \\
\text { rich substrate by the } \\
\text { cow's stomach-principle } \\
\text { (3) Geothermal cooling } \\
\text { of a data center }\end{array}$ & $\begin{array}{l}\text { Scientific project team } \\
\text { (professional and } \\
\text { process promoters) } \\
\text { Practical partners from } \\
\text { the regional energy } \\
\text { system } \\
\text { (key actors) }\end{array}$ \\
\hline
\end{tabular}

Figure 6. Phase 4 of the regional guiding orientation process.

\section{Results}

\subsection{Effectiveness of the Guiding Orientation Process}

A particular aim of this study was to investigate the long-term effectiveness of the considered guiding orientation process and therein spread guiding concepts and guiding design principles beyond the process period. We assume that effectiveness exists when guiding concepts and guiding design principles will be thinking-guided or even action-guided in social exchanges (see Section 2.1).

Thinking-guided effectiveness: Within the conducted interviews we found out that all of the respondents consider the implementation of the communicated guiding design principles for the future as necessary. If a short-term or long-term implementation is required is perceived differently by the interviewees. In addition, a majority of those interviewed stated that they have exchanged or even shared the guiding design principles in other social communities (e.g., in their companies) beyond the process. The two e-mail surveys have shown that all of the companies which replied have gained further qualifications about the introduced low-exergy solutions at exhibitions or events after the series of events.

Action-guided effectiveness: As part of the email-survey $85 \%$ of the surveyed companies indicated that they have taken the presented low-exergy solutions in their planning processes into account and have partially offered these on the refrigeration market. One third of the questioned companies are now offering low-exergy solutions together with other companies which participated at the series of events.

Through the guiding orientation process a participating refrigeration system installer was able to discover one of the introduced conversion technologies, an absorption chiller, as a future business for himself and provides its installation and maintenance as the only supplier in the region by now. With the help of spread publications and the social project external exchange the company was able to win national and international prospects for low-exergy solutions with absorption refrigeration systems. However, the guiding design principles by building und putting low-exergy solutions into operation after the process (factual action) have not been implemented yet.

We also found out that the majority of respondents for whom the guiding design principles were thinking-guided and action-guided preferred innovative, holistic, and (in terms of intergenerational equity) future-oriented technical solutions. This suggests that resilient guiding orientations resonate particularly 
with actors or groups of actors who have world views like holistic in the sense of a closed cycle principle and future orientation.

\subsection{Limitations of the Guiding Orientation Process}

The investigated guiding orientation process contributed to a thinking-guided effectiveness through its four phases but not to guided-action effectiveness in the form of implemented low-exergy solutions after the project ended. This could be attributed to incompatibilities of directional impetuses of further relevant influencing factors with the guiding concept and guiding design principles being focused in the process.

\subsubsection{Incompatible Directional Impetuses of External Influencing Factors}

Lack of regulations toward resilience and climate change adaptation (regulative push): Regulations which require climate-adapted or even resilient technologies in order to increase the security supply and precaution of the energy system have not been institutionalized yet. This could be a reason that the pressure to act and thus to implement such technologies is currently still low. However, regulations with no reference to resilient or climate-adapted systems but to other guiding concepts like efficient systems which can be related to low-exergy solutions or climate-adapted and energy-efficient refrigeration can encourage these guiding principles indirectly. These are in particular laws and regulations which relate to climate protection efforts (e.g., Energy Saving Ordinance).

Inadequate funding toward resilience and climate change adaptation for actors of the energy system (incentive pull): Incentives like funding or subsidies, which provide resilient or climate-adapted technologies, are less compared to climate protection funding and mainly support scientifically oriented projects. Small- and medium-sized enterprises, which can help to diffuse resilient and climate-adapted technologies, often do not have an access to these projects, because they are not provided as part of the funding or they do not have the financial and personnel resources for submissions of applications.

Insufficient supply of market-ready technologies (technology push): The implementation of low-exergy solutions presupposes market-ready technologies which can be used as part of them. In the last 30 years important technological innovations such as in the fields of geothermal probes for the use of near-surface geothermal energy or absorption refrigeration systems have been developed in a small and medium power range [34]. Although these necessary technology components have been already developed, they are muss less offered by installers and in particular by technology manufacturers in the domestic and international market. Thus, the investment costs of such technologies are still very high and the experience with its planning and implementation as well as their combinations with other technologies is still low.

\subsubsection{Incompatible Directional Impetuses of Internal Influencing Factors}

Insufficient integration of all relevant system internal actors (network-specific influencing factors): The implementation of low-exergy solutions as a holistic approach requires networking and an integration of all relevant system internal actors which include plant and technology manufacturers, architecture firms, planning, and plant installation companies and operators. Actors who have the necessary 
expertise in planning holistic and thus complex technological solutions are often not or only very late involved in implementation processes. Reasons for this may lie in the growing demand for all-inclusive packages, which include both the building construction and the design and installation of technology components in hand of a main responsible actor. At the same time these actors do not want to relinquish tasks, which are not part of their professional competence, to achieve the highest fee possible.

Insufficient availability of information and knowledge about low-exergy solutions (organization and individual influencing factors): The implementation of low-exergy solutions requires a certain level of knowledge about and experience with its technology components and their combination options from the supply side. At the same time a source of information is necessary so that the products can be inquired by potential operators. However, at present there is still a lack of experience in planning and implementing low-exergy solutions, among other things, due to the missing market maturity of the technology components which means that at the same time, such systems are not even offered to potential operators.

\subsubsection{Relevance of Guided Orientation Influencing Factors}

The importance of the shown incompatible directional impetuses to give a desired direction can be estimated by the relevance of the turtles model's influencing factors. There is a variety of relations between the influencing factors which act on or in the regional energy system. In this context the external influencing factors regulative push and incentive pull could be particularly relevant because they primarily take effect on other guided orientation influencing factors, e.g., by increasing the demand (market pull) and supply (technology push) of low-exergy technologies and contributing to the networking of system internal actors. Therefore, they are very important parameters toward security and precaution and the compatibility of their directional impetuses should be ensured (see Figure 7).

Within the guiding orientation process the project team tried to reduce the identified incompatibilities of the further influencing factors, for example, the insufficient availability of information and knowledge about low-exergy solutions with the help of the event series in the spreading phase (network-specific influencing factor). However, a need for information still exists and could not yet be met in the context of other events. Furthermore, the project team involved decision-relevant actors of the political system to present them possible regulatory support measures for the implementation of guiding design principles with the aim of encouraging a future institutionalization of these measures in the political system (regulative push and incentive pull). As a result of the guiding orientation process regulatory measures and funding opportunities were indeed discussed in the regional climate and energy policy but not yet institutionalized which, among other things, could explain the missing implementation of low-exergy solutions in the investigated region. Therefore, incompatible directional impetuses can only partially be influenced by guiding orientation processes.

With a view to the flagship projects they have also demonstrated that their implementation depended on further influencing factors. For instance, the project with the absorption refrigeration system which uses waste heat of a combined heat and power plant and includes a thermal buffer in order to cool turkey barns could already be successfully implemented. Surely, the operator was driven to implement the low-exergy solution in order to obtain efficiency gains and the combined heat and power (CHP) bonus by utilizing waste heat (incentive pull) as well as to become independent of energy suppliers to some extent. On the other side the intended system services, particularly the 
cooling of turkeys, could have been implemented more cost-effective. With the help of the great commitment of the involved regional stakeholders who were open to new ideas and were not afraid to take financial risks, the refrigeration system could nevertheless be constructed. In respect of its contribution to resilience the cooling installation has increased the animals' robustness against climate change because climate change-induced heat waves have resulted in a higher mortality rate and thus the established cooling of the barns was helpful to counteract this. Additionally, the use of local waste heat instead of electricity removes strain from the electricity grid. However, the efficiency gain may have been the most important incentive for the practical partners.

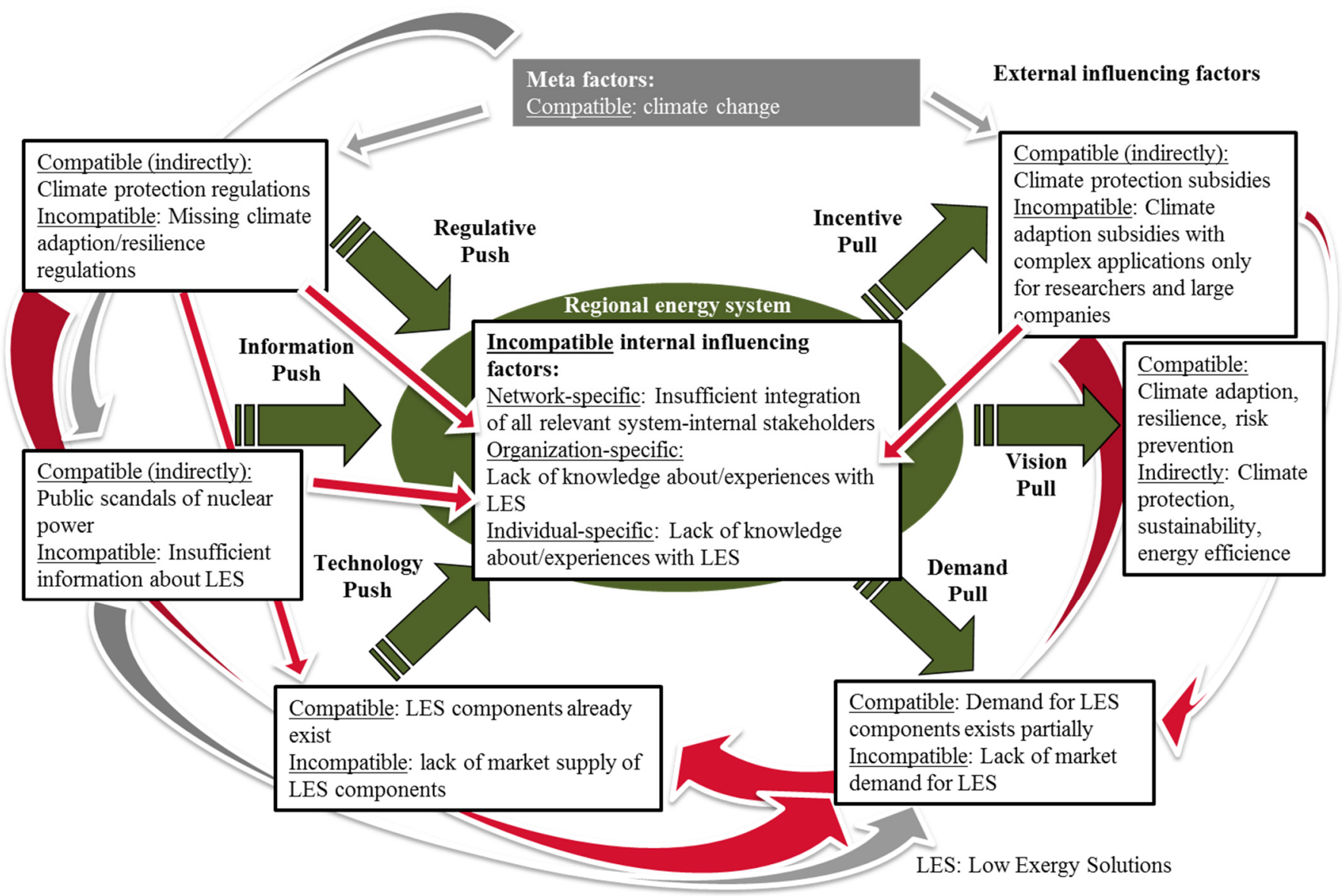

Figure 7. Filled turtles model of the Northwestern Gemany energy system showing compatible and incompatible directional impetuses in the context of the guiding design principle of "low-exergy solutions (LES)".

The other flagship projects, the biogas plant for converting cellulose-rich substrates by a cow's stomach-principle as well as the geothermal cooling of a data center, contributed to a resilient energy system to an even greater extent. On the one hand, the cooling demand of servers in data centers which is expected to increase in the future by higher average temperatures and additional heat waves could be covered by low-exergy solutions like geothermal probes instead of electrically driven cooling systems. Among other things, this would reduce a burden on the electricity grid and thus increase the security of supply (systemic resilience). Furthermore, because of the implementation of several different cooling systems (geothermal, compression, free) the redundancy of the energy system could be increased (local resilience). Similar to the first presented flagship project committed actors like the operator and 
installer who were very interested in innovative solutions but also in an image improvement through "green" solutions and in saving energy contributed to the implementation of the geothermal probes. However, due to difficult geological conditions the project is still under construction.

The third flagship project, the use of cellulose-rich substrate instead of conventional biomass like energy corn in biogas plants (RuSiTech-plant), has also not yet been fully implemented. Problems with the release of a cow's stomach-principle invention and high investment costs as well as ever changing and complex regulative conditions have led to the current project status, but it has still a chance of success through the high support of the investor and interest in the new principle. The idea could be an option in order to avoid conflicts between the cultivation of food and energy crops. Besides its greater efficiency in contrast to traditional biogas plants the RuSiTech-plant implies resource diversity in using different kinds of already existing fermenting substrate such as straw, hay and leaves and thus enhances the local resilience.

Consequently, all of the flagship projects contribute to a more or less high resilience of the energy system. However, not only the prospect of a such resilient system but also other influencing factors like regulative conditions or the commitment of the practical actors have led to the implementation status of the projects.

\subsection{Effectiveness Factors for the Guiding Orientation Process}

Which factors could be identified as particularly important for the effectiveness of the presented guiding orientation process and its spread guiding concept and guiding design principles? Following Beucker et al. [38] we distinguish between content-related factors concerning the effectiveness of the guiding concept and its guiding design principles as well as process-related factors which relate to the process and its four phases (see Table 2).

Table 2. Content-related and process-related effectiveness factors for the guiding orientation process.

\begin{tabular}{|c|c|}
\hline $\begin{array}{l}\text { Content-Related } \\
\text { Effectiveness Factors }\end{array}$ & Explanations in Relation to the Case Study \\
\hline $\begin{array}{l}\text { Connection to world } \\
\text { views and simultaneous } \\
\text { offer of chances of } \\
\text { implementation }\end{array}$ & $\begin{array}{l}\text { The guiding orientation processes and its spread guiding concept of resilient systems should } \\
\text { be an option to design transformation processes toward desired world views like security } \\
\text { and precaution. This may lead to the assumption that the guiding concept is connected to } \\
\text { these world views which has been derived from them. } \\
\text { At the same time it can offer action-oriented guiding design principles which make the } \\
\text { implementation appear feasible like low-exergy solutions. }\end{array}$ \\
\hline Capability of response & $\begin{array}{l}\text { The guiding concept of resilient systems resonated with the scientific project team because } \\
\text { it was connected to deeply rooted desires like security and precaution of individuals and } \\
\text { social communities. } \\
\text { In contrast, outside the academic discourse the guiding concept led to misunderstandings. } \\
\text { Nevertheless, by translating into regional-specific guiding design principles they contributed } \\
\text { to the guiding concept's capability of response. }\end{array}$ \\
\hline $\begin{array}{l}\text { Motivational element } \\
\text { of surprise }\end{array}$ & $\begin{array}{l}\text { The foreign term of resilience caused irritation but thus, it remained firmly embedded in } \\
\text { many minds of the involved actors. } \\
\text { By showing new combinations of conventional technologies the guiding design principles } \\
\text { created great interest among the actors of the regional energy system. }\end{array}$ \\
\hline
\end{tabular}


Table 2. Cont.

\begin{tabular}{|c|c|}
\hline $\begin{array}{l}\text { Content-Related } \\
\text { Effectiveness Factors }\end{array}$ & Explanations in Relation to the Case Study \\
\hline $\begin{array}{l}\text { Connection to other } \\
\text { guiding concepts [39] }\end{array}$ & $\begin{array}{l}\text { The guiding design principles exhibited not only a connection to the guiding concept of } \\
\text { resilient systems but also to the guiding concept of efficient systems, which are far more } \\
\text { established in the regional energy system than resilience is. } \\
\text { With this connection option their response capability could be increased in many of the } \\
\text { involved system internal actors. }\end{array}$ \\
\hline $\begin{array}{l}\text { Provision of different } \\
\text { ways of interpretation }\end{array}$ & $\begin{array}{l}\text { The guiding concept of resilient systems offered diverse options of interpretation and thus } \\
\text { initiated intensive communication processes in the project. } \\
\text { In this course the scientific team could develop its own pre-understanding of the } \\
\text { guiding concept and specified it to guiding design principles in exchange with project } \\
\text { external actors. }\end{array}$ \\
\hline $\begin{array}{l}\text { Problem-solving } \\
\text { orientation }\end{array}$ & $\begin{array}{l}\text { The guiding concept of resilient systems suggested new pathways which contributed to the } \\
\text { security of supply and precaution. } \\
\text { These are topics which will face challenges in the future due to far-reaching transformation } \\
\text { processes caused by political targets for climate protection and possible consequences of } \\
\text { climate change. }\end{array}$ \\
\hline $\begin{array}{l}\text { Process-Related } \\
\text { Effectiveness Factors }\end{array}$ & Explanations in Relation to the Case Study \\
\hline $\begin{array}{l}\text { Taking up of world } \\
\text { views with problem- } \\
\text { solving oriented } \\
\text { guiding ideas and } \\
\text { specification of guiding } \\
\text { concepts and guiding } \\
\text { design principles with } \\
\text { the help of (scientific) } \\
\text { professional promoters }\end{array}$ & $\begin{array}{l}\text { The development of a problem-solving oriented idea such as resilience needs actors with } \\
\text { expertise who have a creative environment and resources and are also legitimized to other } \\
\text { involved actors because of their expertise to carry out such processes. } \\
\text { The world views of security and precaution being relevant in the present energy system has } \\
\text { been taken up which could be done by an intense debate about the limits of the guiding idea } \\
\text { of climate adaptation. Over the exchange about definitional terms the project team } \\
\text { developed resilience to a project internal guiding concept and contributed significantly to } \\
\text { the specification of the guiding concept within legitimated discussions with project } \\
\text { external actors. }\end{array}$ \\
\hline
\end{tabular}

Taking into account the knowledge from everyday life by the mutual exchange with non-scientific actors of the regional energy system was very important to specify guiding

Involvement of system relevant actors to specify guiding design principles design principles with capability of response.

Therefore, among other things, the project team determined that the regional energy system has to be designed more resilient in relation to indirect climate change impacts and not only to direct ones. In this way, the guiding design principle of low-exergy solutions could be developed which would meet both of these requirements.

The practice partners who participated in the flagship projects were important key actors. As primarily visionary, innovative and future-oriented actors they contributed to the

Involvement of potential key actors early in the process spreading and implementation of the guiding design principles by informing other end-users about low-exergy solutions and participating in the establishment of the flagship technologies.

The project team involved them early in the process as project external actors and thus, they co-designed the direction of the later flagship projects, which supported their identification with guiding design principles and guiding concepts. 
Table 2. Cont.

\begin{tabular}{|c|c|}
\hline $\begin{array}{l}\text { Process-Related } \\
\text { Effectiveness Factors }\end{array}$ & Explanations in Relation to the Case Study \\
\hline $\begin{array}{l}\text { Specification of guiding } \\
\text { design principles into } \\
\text { application examples } \\
\text { and spreading them }\end{array}$ & $\begin{array}{l}\text { By showing exemplary low-exergy solutions in the series of events the project team could } \\
\text { substantial clarify the guiding design principles for the participants. } \\
\text { Therefore, the team could not only make the low-exergy solutions more transparent but they } \\
\text { could also illustrate examples in what kinds of ways technology components, which the } \\
\text { participants have already established in their companies, can usefully be combined. }\end{array}$ \\
\hline $\begin{array}{l}\text { Regular check of the } \\
\text { effectiveness of guiding } \\
\text { design principles and } \\
\text { adaptation of them }\end{array}$ & $\begin{array}{l}\text { In the case study the project team checked regularly the effectiveness of the guiding design } \\
\text { principles and application examples according to the content-related effectiveness factors. } \\
\text { Among other things, the team selected application examples of low-exergy solutions in } \\
\text { terms of the criteria innovativeness, feasibility, potential of resilience, and multiplier effects } \\
\text { within the innovation potential analysis to increase their effectiveness. This required } \\
\text { literature research and expert interviews. }\end{array}$ \\
\hline $\begin{array}{l}\text { Spreading guiding } \\
\text { concepts and guiding } \\
\text { design principles } \\
\text { appropriately to the } \\
\text { addressees }\end{array}$ & $\begin{array}{l}\text { The project team had to face the challenge to prepare and formulate the complex issue of } \\
\text { low-exergy solutions adequately for the refrigeration industry. } \\
\text { In the case of the event series the researchers were able to spread the guiding design } \\
\text { principles successfully to the participants within the addressee-oriented and target } \\
\text { group-specific event format in terms of the application examples visits and the moderation } \\
\text { of discussions. } \\
\text { By publishing at conferences as well as in professional journals they initiated a demand for } \\
\text { low-exergy solutions on a national and international level. }\end{array}$ \\
\hline $\begin{array}{l}\text { Regular check of the } \\
\text { compatibility of } \\
\text { guiding design } \\
\text { principles and the } \\
\text { adaptation of them or } \\
\text { influencing the } \\
\text { identified incompatible } \\
\text { directional impetuses }\end{array}$ & $\begin{array}{l}\text { In the case study the project team checked regularly incompatible directional impetuses of } \\
\text { further influencing factors in the phases of specification and spreading. } \\
\text { Within analyses and exchanges with system relevant actors they were able to identify } \\
\text { incompatible directional impetuses of external and internal influencing factors. } \\
\text { As a result, they adapted the guiding design principles and influenced incompatible } \\
\text { directional impetuses, among other things, with an informative event series and an } \\
\text { integration of decision-relevant actors of the political system. }\end{array}$ \\
\hline
\end{tabular}

\subsection{Transferability of the Results to other German Regions and Nations}

To what extent are the investigated case study and its results relevant for other regions in Germany and countries in the international context?

According to [40,41] in 2009 the electrical demand for cooling (e.g., products, production processes, buildings) in Germany is about 71 Terawatt, which corresponds to a share of $14 \%$ of total German electricity consumption. Due to higher average temperatures and additional heat waves as a result of climate change increasing cooling needs will be expected in the future throughout Europe despite the demographic change and its prognosticated decrease requirement for cooling [42]. Regarding to the fact that the electricity consumption for cooling increases particularly at midsummer temperatures when the conventional electricity generation is limited due to a lack of cooling water for power stations which applies not for the Northwest Region of Germany but for other countries [43], the relevance of low-exergy technologies in order to cool buildings, products, and production processes increases much more in Germany and other nations. 
Beside the aforementioned (future) demand for cooling services other German regions beyond the Northwest Region have the necessary potential for the implementation of low-exergy solutions. On the one hand, exergetic low ambient energy sources or residual and waste streams are available. For example, Schleswig-Holstein and Mecklenburg-Western Pomerania have also a high potential for the use of geothermal heat or cool among the Metropolitan Region Bremen-Oldenburg [44]. On the other hand, many conventional technology components could be substitutes for low-exergy technology components for resilience or climate protection reasons. For instance, studies have shown that the food industry in Germany operates around 16,500 cooling units, mainly of the compression type, of which a large number could be substituted by absorption chillers [45]. Therefore, the application of low-exergy solutions in the cooling area could be also important for other German regions and even beyond national borders.

With a view to the mentioned external factors which directional impetuses are incompatible with the guiding concept and guiding design principles (regulations and funding toward resilience and climate change adaptation in Germany) they do not apply only for the regional but for the German energy system as well. The mentioned internal influencing factors and effectiveness factors were indeed collected in relation to the presented case study and thus to the Northwest Region but can be transferred to other regions because we assume that the constellation of actors would be similar to other regional energy systems in Germany.

\section{Discussion and Outlook}

What do the research results mean for the already indicated guiding principle discourse of the technological genesis and social research by calling the targeted guiding orientation's effectiveness into question?

The presented guiding orientation process in this study, a process in which the propagandized resilient systems in form of guiding design principles low-exergy solutions or climate-adapted and energy-efficient refrigeration, demonstrates that a thinking and action-guided effectiveness may have been achieved. To obtain this, certain steps concerning the suggested phase model as well as taking into account the related data of the effectiveness factors have to be fulfilled; also, relevant world views have to be taken up with a guiding idea, from specifying guiding concepts and guiding design principles into their spreading and implementation. In addition, a guiding concept may only be suitable for such a process under specific conditions as it is demonstrated among the content-related efficiency factors.

At the same time, the increased guiding concepts and the guiding design principles have not been action-guided yet so that they were able to end in an actual implementation of low-exergy solutions which can be explained by incompatible directional impetuses of other relevant guiding influencing factors with guiding concepts and guiding design principles. The initial assumption is hereby confirmed that a desired direction can become apparent by a synchronic interaction of guiding influencing factors. A targeted increase of the compatibilities presents therefore an important effectiveness factor which in the context of guiding orientation processes needs to be addressed but can only be influenced to a limited extent as it has been presented in this study.

It has been demonstrated that in addition to the previously mentioned compatibility of the guiding influencing factors do the guiding concepts and guiding design principles' capability of response have 
a great importance to the effectiveness of the guiding orientation process which with the interaction with actors of the regional energy system needs to be checked on a regular basis. In this context was the resilient systems' guiding concept less appropriate due to its low-use in common usage despite its relevance to socially relevant world views such as security and precaution and the demonstrated design elements. Thus, a translation of the guiding concept for its recipients during the course of the guiding orientation's process took place wherewith also the in academic discussion often criticized vagueness of the resilience concept was counteracted [46].

The guiding design principle of the climate-adapted and energy-efficient refrigeration developed in several concretizing phases. This may be slightly irritating as there is actually a state of tension between resilience in its approach of confronting redundancies and storage capacity and the efficiency. Although the discourse on sustainability was able to include relevant guiding concepts which provided efficient systems, there was also the possibility the contents of the intended guiding concept of resilient systems being lost. This can mean that the addressed actors of the guiding orientation process might rather associate climate-adapted and energy-efficient refrigeration with energy-efficient and climate protection efforts and distribute this content rather than dealing with climate-adapted or even resilience activity with direct and indirect consequences in the sense of security of supply. Consequently, it should be taken into consideration that when guiding design principles are being concretized; guiding concepts should retain their importance. This certainly requires that the actors share a common understanding of the guiding concepts which, as in the case of resilience, can be interpreted and defined in a variety of ways and which may also present a challenge [46].

Moreover, the term of resilience as it is used in the understanding of this project is in a constant state of tension with the overriding sustainability and its world views. While sustainability is based on the preservation of the present, by which the deeply rooted desire for stability is intended, resilience can mean the change of system structure. This might meet resistance from established energy system actors or even from the structurally conservative energy system [26,47]. Accordingly, the resilience approach can be resonance-capable by actors who have the future in mind, are open for innovative and comprehensive concepts and perceive with this transformation processes as learning processes [11].

In order to guarantee a capability of response and so that the guiding concepts' effectiveness or guiding design principles are achieved, a sort of preliminary investigation of the world views of the involved actors in the context of a qualitative survey is necessary which seems to be very work-intensive. Instead of only imposing guiding concepts and guiding design principles to potential addresses linked to the hope of response these actors should be involved early in the guiding orientation process and the development of the guiding design principles. This can help to ensure that the actors identify themselves more easily with the guiding concepts and guiding design principles in the course of communication processes and thus become guiding orientation representatives what has been shown in the presented guiding orientation process and has also been proposed in other studies [15].

In comparison to other representations of the future like visions and scenarios, guiding concepts have the advantage to combine desirability as well as feasibility with their relation to world views and guiding design principles and thus may be particularly capable of being resonant. Vision processes, however, could help to identify a desired direction and scenario processes could assist in specifying guiding concepts into feasible guiding design principles and in checking (in)compatible directional 
impetuses of further influencing factors. For instance, the "integrated roadmapping supported by guiding orientations" presents a combination of such processes [38].

With a view to subsequent work the proposed flow of a guiding orientation process could be applied to other case studies in the energy system while taking into account the mentioned effectiveness factors with the intension to check their effectiveness [48]. In particular non-scientific initiated guiding orientation processes (e.g., by cities or municipalities) would be of interest [49]. Furthermore, with the intension to remove strain from the electricity grid by implementing low-exergy solutions the project team in the shown case study focused on maintaining system services with regard to technical parameters (e.g., provided connected load). Non-technical parameters like competitiveness, social acceptance or global warming potential (efficiency) were indeed taken into account by the turtles model or rather by the guiding concept efficient systems but the question of the appropriate balance should be considered even more in guiding processes. This also includes the issue to what extent we have to pay attention to resilience in comparison with other strategic elements of sustainability (efficiency, sufficiency, consistency) in directing transformation processes toward desired world views as security, precaution, stability and justice.

\section{Acknowledgments}

This article was made possible, in part, through support by a grant from the German Ministry for Education and Research as part of its KLIMZUG initiative. Moreover, the authors thank the interviewees for their participation and Jens Clausen, Thomas Blöthe, Stefan Gößling-Reisemann, Jakob Wachsmuth, Sönke Stührmann and Torben Stührmann for their helpful comments. Finally, the authors thank the two anonymous reviewers for their helpful and constructive criticism and the (assistant) editors for their support.

\section{Author Contributions}

All authors contributed to the conceptualization of the article. Urte Brand carried out the main body of research. Arnim von Gleich reviewed the work continually.

\section{Conflicts of Interest}

The authors declare no conflict of interest.

\section{References and Notes}

1. Rotmans, J.; Loorbach, D. Towards a better understanding of transitions and their governance. A systemic and reflexive approach. In Transitions to Sustainable Development: New Directions in the Study of Long Term Transformative Change; Grin, J., Rotmans, J., Schot, J.W., Eds.; Routledge: New York, NY, USA, 2010; pp. 105-220.

2. Schot, J.W.; Rip, A. The past and future of constructive technology assessment. Technol. Forecast. Soc. Chang. 1997, 54, 251-268. 
3. Ahrens, A.; Braun, A.; von Gleich, A.; Heitmann, K.; Lißner, L.; Effinger, A.; Weiß, M.; Wölk, C. Hazardous Chemicals in Products and Processes: Substitution as an Innovative Process; Physica-Verlag: Heidelberg, Germany; New York, NY, USA, 2006.

4. Von Gleich, A.; Stührmann, S.; Brand, U.; Gößling-Reisemann, S. Directed Innovation towards Climate Adaptation-Resilience as Guiding Principle (Leitbild) in Energy Supply of Germany's Northwest. In Proceedings of the ISEE 2010 Conference-Advancing Sustainability in a Time of Crisis, Oldenburg, Germany, 22-25 August 2010.

5. Hellige, H.D. Technikleitbilder auf dem Prüfstand: Leitbild-Assessment aus Sicht der Informatik- und Computergeschichte; Edition Sigma: Berlin, Germany, 1996. (In German)

6. Maaß, S. Maschine, Partner, Medium, Welt. Eine Leitbildgeschichte der Software-Ergonomie. In Leitbilder der Informatik- und Computer-Entwicklung; Hellige, H.D., Ed.; Artec: Bremen, Germany, 1994; Volume 33, pp. 329-342. (In German)

7. Tepper, A. Computer für jeden und alles. Zur Rolle von Leitbildern in der Entwicklungsgeschichte des Personalcomputers. In Leitbilder der Informatik- und Computer-Entwicklung; Hellige, H.D., Ed.; Artec: Bremen, Germany, 1994; Volume 33, pp. 345-375. (In German)

8. Schippl, J.; Grunwald, A. Energiewende 2.0-Vom technischen zum soziotechnischen System?-Einführung in den Schwerpunkt. Technikfolgenabschätzung 2013, 22, 4-10. (In German)

9. Gößling-Reisemann, S.; Bardt, H.; Biebeler, H.; Dördelmann, O.; Herrmann, A.; Stührmann, S.; Wachsmuth, J. Klimawandel: Regionale Verwundbarkeit der Energieversorgung in Deutschland. Energ. Tagesfr. 2012, 62, 60-63. (In German)

10. Klemmer, P.; Lehr, U.; Löbbe, K. Environmental Innovation: Incentives and Barriers, 1st ed.; Analytica: Berlin, Germany, 1999.

11. Wachsmuth, J.; Petschow, U.; Brand, U.; Fettke, U.; Pissarskoi, E.; Fuchs, G.; Dickel, S.; Kljajic, M. Richtungsgebende Einflussfaktoren im Spannungsfeld von Zentralen vs. Dezentralen Orientierungen bei der Energiewende und Ansatzpunkte für ein Leitkonzept Resilienz. RESYSTRADiskussionspapier 1; University of Bremen/IÖW: Bremen/Berlin, Germany, 2015. Available online: http://www.resystra.de/files/publikationen/richtungsgebende-einflussfaktoren.master.pdf (accessed on 8 July 2015). (In German)

12. Dierkes, M.; Hoffmann, U.; Marz, L. Visions of Technology: Social and Institutional Factors Shaping the Development of New Technologies; Palgrave Macmillan: London, UK, 1996.

13. Fichter, K.; Beucker, S.; Noack, T.; Springer, S. Entstehungspfade von Nachhaltigkeitsinnovationen: Fallstudien und Szenarien zu Einflussfaktoren, Schlüsselakteuren und Internetunterstützung; Fraunhofer IRB-Verl: Stuttgart, Germany, 2007. (In German)

14. Brand, U. Abschlussbericht zum Umsetzungsbaustein 1: "Schaffung von Gemeinsamer Identität und Verantwortung der Bewohner durch energie- und kosteneffiziente Sanierungs- und Entwicklungsplanung"-Teilprojekt: Analyse und prozessbegleitende Untersuchung der richtungsgebenden Einflussfaktoren; Projekt ZukunftsWerkStadt Leutkirch; University of Bremen: Bremen, Germany, 2013. (In German)

15. Giesel, K.D. Leitbilder in den Sozialwissenschaften: Begriffe, Theorien und Forschungskonzepte, 1st ed.; VS Verlag für Sozialwissenschaften: Wiesbaden, Germany, 2007. (In German) 
16. Aulenbacher, B. Rationalisierungsleitbilder-Wirkmächtig, weil machtvoll und machbar. In Sinnformeln: Linguistische und Soziologische Analysen von Leitbildern, Metaphern und Anderen Kollektiven Orientierungsmustern; Geideck, S., Liebert, W.-A., Eds.; De Gruyter: Berlin, Germany; New York, NY, USA, 2003; Volume 2, pp. 105-118. (In German)

17. Mayring, P. Qualitative content analysis-Research instrument or mode of interpretation? In The Role of the Researcher in Qualitative Psychology, 1st ed.; Kiegelmann, M., Ed.; Huber: Tübingen, Germany, 2002; Volume 2, pp. 139-148.

18. Haan, G.D. Leitbild Analysis-A New Method for Future Science; 2002. Available online: http://www.institutfutur.de/_service/download/leitbildanalysis.pdf (accessed on 29 May 2015).

19. Siebenhüner, B.; von Gleich, A. Regionale Klimaanpassung im Küstenraum: Einleitung. In Regionale Klimaanpassung im Küstenraum; von Gleich, A., Siebenhüner, B., Eds.; Metropolis-Verlag: Marburg, Germany, 2015; pp. 9-19.

20. IPCC. Climate Change 2014: Synthesis Report. Contribution of Working Groups I, II and III to the Fifth Assessment Report of the Intergovernmental Panel on Climate Change. 2014. Available online: http://ipcc.ch/report/ar5/syr (accessed on 29 May 2015).

21. Holling, C. Engineering resilience vs. ecological resilience. In Engineering within Ecological Constraints; Schulze, P.C., Ed.; National Academy Press: Washington, DC, USA, 1996; pp. 31-44.

22. Brand, F. Ecological Resilience and Its Relevance within a Theory of Sustainable Development; UFZ-Report 03/2005. Available online: https://www.ufz.de/export/data/global/29235_ufz_bericht_ 03_2005.pdf (accessed on 8 July 2015).

23. Walker, B.; Carpenter, S.R.; Anderies, J.; Abel, N.; Cumming, G.; Janssen, M.; Lebel, L.; Norberg, J.; Peterson, G.; Pritchard, R. Resilience Management in Social-Ecological Systems: A Working Hypothesis for a Participatory Approach. Available online: http://www.ecologyandsociety.org/ vol6/iss1/art14/ (accessed on 8 July 2015).

24. Gunderson, L.H.; Holling, C.S. Panarchy: Understanding Transformations in Human and Natural Systems; Island Press: Washington, DC, USA, 2002.

25. Gößling-Reisemann, S.; von Gleich, A.; Stührmann, S.; Wachsmuth, J. Climate change and structural vulnerability of a metropolitan energy supply system-The case of Bremen-Oldenburg in Northwest Germany. J. Ind. Ecol. 2012, 17, 846-858.

26. Von Gleich, A.; Gößling-Reisemann, S.; Stührmann, S.; Woizeschke, P. Resilienz als Leitkonzept-Vulnerabilität als analytische Kategorie. In Theoretische Grundlagen für Klimaanpassungsstrategien; Fichter, K., von Gleich, A., Pfriem, R., Siebenhüner, B., Eds.; Universities of Bremen and Oldenburg: Bremen/Oldenburg, Germany, 2010; pp. 13-49. (In German)

27. Lovins, A.B.; Lovins L.H. Brittle Power: Energy Strategy for National Security; Brick House Publishing Company: Andover, MA, USA, 1982.

28. Shannon, C.E.; Weaver, W.; Blahut, R.E.; Hajek, B. The Mathematical Theory of Communication; University of Illinois Press: Urbana, IL, USA, 1998.

29. Gößling-Reisemann, S.; Stührmann, S.; Wachsmuth, J.; von Gleich, A.; Blöthe, T. Klimaanpassung und Resilienz in der Energiewirtschaft. In Regionale Klimaanpassung im Küstenraum; von Gleich, A., Siebenhüner, B., Eds.; Metropolis-Verlag: Marburg, Germany, 2015; pp. 182-206. (In German) 
30. Chaudry, M.; Ekins, P.; Ramachandran, K.; Shakoor, A.; Strbac, G.; Wang, X.; Whitaker, J. Building a Resilient UK Energy System: Research Report; UK Energy Research Centre: London, UK; Oxford, UK; Edinburgh, UK, 2011.

31. Wardekker, J.A.; de Jong, A.; Knoop, J.M.; Sluijs, J.P. Operationalising a resilience approach to adapting an urban delta to uncertain climate changes. Technol. Forecast. Soc. Chang. 2010, 77, 987-998.

32. Leyens, D.; Engelhard, P.; Reck, H. Klimaanpassung in der Energiewirtschaft. Energ. Tagesfr. 2012, 62, 49-52. (In German)

33. Clausen, J.; Bierter, W.; Winter, W. Screening Innovationspotenziale der Regionalen Energiewirtschaft Teil A: Low Exergy Solutions; Internal Report; Borderstep Institute: Berlin, Germany, 2011.

34. Clausen, J. Innovationspotenzialanalyse und Roadmap Klimaangepasste Kältetechnik; Potenziale und Innovationssystem: Bremen, Germany, 2014. (In German)

35. Gößling-Reisemann, S.; Blöthe, T. Low Exergy Solutions as a Contribution to Climate Adapted and Resilient Power Supply. 2012. Available online: http://www.researchgate.net/profile/Stefan Goessling-Reisemann/publication/266885636_Low_Exergy_Solutions_as_a_contribution_to_climate_ adapted_and_resilient_power_supply/links/545cd9ca0cf295b5615e5f55.pdf (accessed on 8 July 2015).

36. Stührmann, S.; Gößling-Reisemann, S.; Blöthe, T.; Wachsmuth, J.; Gleich, A.V. Regional Climate Adaptation Solutions towards Resilient Energy Systems. Available online: http://www.regklam.de/ fileadmin/ccrr-2013/abstracts/Session_2b_CCRR2013_abstracts.pdf (accessed on 8 July 2015).

37. An implementation could also be done by an initialization of guiding concepts and guiding design principles, for example, in the form of laws and regulations.

38. Beucker, S.; Brand, U.; Fichter, K.; von Gleich, A. Leitorientiertes Integriertes Roadmapping; Universities of Bremen and Oldenburg: Bremen/Oldenburg, Germany, 2011. (In German)

39. Other previous inducted studies have shown that guiding concepts and guiding design principles could take effect on competition with other guiding concepts, for instance solar economy which competed with nuclear industry.

40. Preuß, G. Energiebedarf von Kältetechnik in Deutschland: Eine Abschätzung des Energiebedarfs von Kältetechnik in Deutschland nach Einsatzgebieten; VDMA: Frankfurt am Main, Germany, 2011. (In German)

41. Arnemann, M. Energy Efficiency of Refrigeration Systems, 2012. Available online: http://docs.lib.purdue.edu/iracc/1356/ (accessed on 8 July 2015).

42. Kenkmann, T.; Bürge, V. Contribution of Renewable Cooling to the Renewable Energy Target of the EU; Policy Report. 2012. Available online: http://www.oeko.de/oekodoc/1497/2012-066en.pdf (accessed on 8 July 2015).

43. Rothstein, B.; Parey, S. Impacts of and adaptation to climate change in the electricity sector in Germany and France. In Climate Change Adaptation in Developed Nations: From Theory to Practice; Ford, J.D., Berrang-Ford, L., Eds.; Springer: Dordrecht, The Netherlands; New York, NY, USA, 2011; Volume 42, pp. 231-241.

44. Stober, I.; Fritzer, T.; Obst, K.; Schulz, R. Deep Geothermal Energy: Application Possibilities in Germany; Federal Ministry for Economic Affairs and Energy (BMWi): Berlin, Germany, 2014. 
45. Zürich, S. Ammoniak/Wasser-Absorptionskälteanlagen von AGO AG Energie + Anlagen: Beim Kühlen bis zu 80 Prozent Primärenergie einsparen. BHKS-Almanach 2011, 34-36. Available online: http://www.btga.de/der-bhks/bhks-almanach/test2.php (accessed on 8 July 2015). (In German)

46. Gross, M. Experimentelles Nichtwissen: Umweltinnovationen und die Grenzen SozialÖkologischer Resilienz; Transcript Verlag: Bielefeld, Germany, 2014. (In German)

47. Hellige, H.D. Transformationen und Transformationsblockaden im Deutschen Energiesystem; Eine strukturgenetische Betrachtung der aktuellen Energiewende: Bremen, Germany, 2012. (In German)

48. This will present the project "RESYSTRA—Resilient Design of Energy Systems Using the Examples of the Transformation Options EE-Methane System and Regional Self-Sufficiency" funded by the German Federal Ministry.

49. The city of Wolfhagen in Hessen (Germany) provides a guiding orientation process with the guiding concept of a resilient energy system.

(C) 2015 by the authors; licensee MDPI, Basel, Switzerland. This article is an open access article distributed under the terms and conditions of the Creative Commons Attribution license (http://creativecommons.org/licenses/by/4.0/). 